\title{
Erratum to: Evaluation of the Use of Selective PCR Amplification of LPS Biosynthesis Genes for Molecular Typing of Leptospira at the Serovar Level
}

\author{
Josefa Bezerra da Silva $\cdot$ Eneas Carvalho • \\ Rudy A. Hartskeerl • Paulo L. Ho
}

Published online: 8 October 2010

(C) Springer Science+Business Media, LLC 2010

\section{Erratum to: Curr Microbiol}

DOI 10.1007/s00284-010-9738-7

The original version of the article entitled "Evaluation of the Use of Selective PCR Amplification of LPS Biosynthesis Genes for Molecular Typing of Leptospira at the Serovar Level" (Current Microbiology, DOI: 10.1007/ s00284-010-9738-7) contained a mistake. The presentation of Fig. 2 was incorrect. The corrected figure is given below.

The online version of the original article can be found under doi:10.1007/s00284-010-9738-7.

J. Bezerra da Silva $\cdot$ E. Carvalho $\cdot$ P. L. Ho ( $₫)$

Centro de Biotecnologia, Instituto Butantan,

05503-900 São Paulo, SP, Brazil

e-mail: hoplee@butantan.gov.br

E. Carvalho

e-mail: eneas@butantan.gov.br

R. A. Hartskeerl

KIT Biomedical Research, Royal Tropical Institute,

Amsterdam, The Netherlands
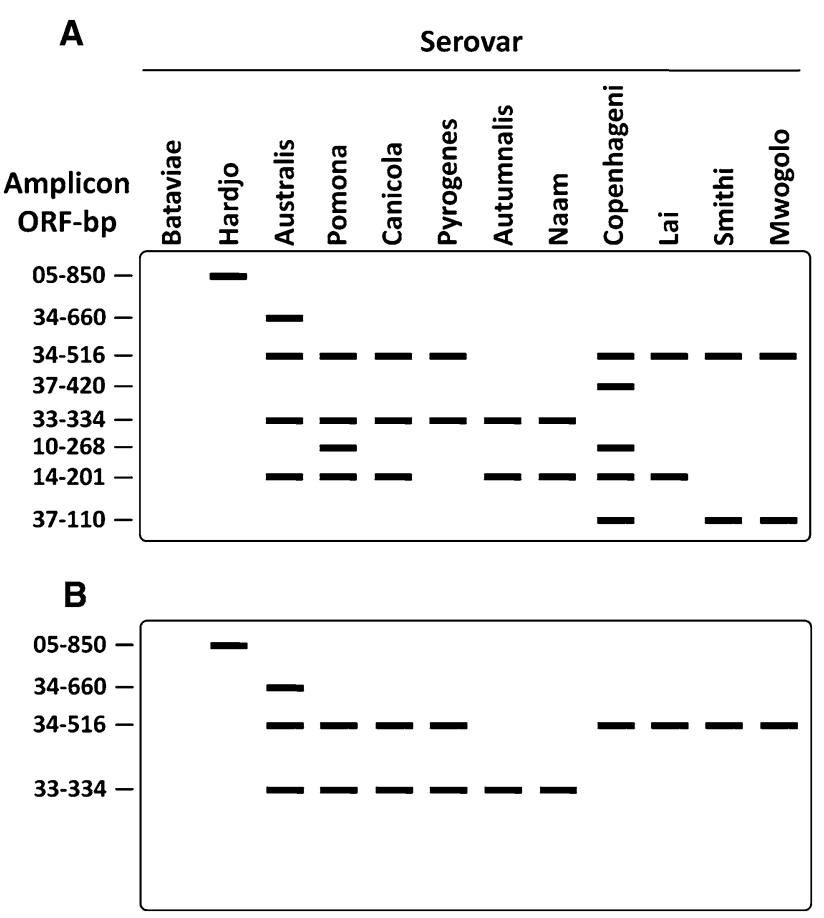

Fig. 2 Schematic representation of the expected electrophoretic profile of amplicons. (a) Expected profile of multiplex PCR products, using all the eight paired primers. (b) Expected profile of multiplex PCR products, using a subset of four paired primers (pairs 05-850, 34-660, 34-516, and 33-334). In both figures, we used Hardjo subtype Hardjoprajitno 